\title{
第25回 九州小児ネフロロジー研究会
}

\author{
日 時：2011年 7 月 30 日 $\cdot 31$ 日 \\ 会 場：柳川リハビリテーション学院 \\ 世話人：田中征治 (久留米大学医療センター小児科) \\ (受付日: 平成24年 1 月 31 日 採用日: 平成24年 2 月 8 日)
}

\section{Invited Lecture}

小児例からみた腎病理診断標準化

\section{Guest Lecture I}

長崎大学大学院医歯薬医歯薬学総合研究科病態病理学 田口 尚先生

ゲノムワイド連鎖解析・遺伝性腎疾患・古典的生理学の統合による腎機能・病態の理解

東邦大学大橋病院小览科 関根孝司先生

\section{Guest Lecture II}

小児期発症難治性ネフローゼに対するリツキシマブ治療の可能性

国立成育医療研究センター腎臓・リウマチ・膠原病科＼cjkstart伊藤秀一先生

\section{Guest Lecture III}

腎障害を来す小览下部尿路疾患

\section{Short LectureI}

佐賀大学医学部泌尿器科 野口 满先生

Galloway-Mowat syndrome

熊本大学医学部小児科 中里仁史先生

\section{一般演題}

1. 1 型糖尿病に微小変化型ネフローゼ症候群を合併した 1 症例

2.リツキシマブ単回投与を行い，その後ミコフェノール酸モフェチルを用いて

寬解を維持しているステロイド抵抗性ネフローゼ症候群の 5 歳女児例

九州大学医学部小児科 西山 慶，他

3．サイトメガロウイルス感染後に慢性血小板減少症をきたした腎移植後の 1 例

熊本大学医学部小児科 服部希世子，他

4.学校検尿でみつかった膜性増殖性系球体腎炎の1女览例

鹿児島大学医学部小児科 永迫博信, 他

5 . 血尿・低補体血症で発症し， 3 年後に腎生検を施行した MPGN の 1 例

愛媛県立今治病院小児科 手塚優子，他

6. 抗 Factor H 抗体にて発症した atypical HUS（aHUS）の 1 例

7. Hyponatremic hypertensive syndrome（HHS）を呈した 1 女児例

8．発熱を契機に腎性尿崩症と診断した 1 例

9. 精神運動発達遅滞を伴う児に腹膜透析を導入した 2 例

国立病院機構西別府病院小児科 植村篤実，他 佐賀大学医学部小览科 岡 政史, 他 長崎大学医学部小児科 原田定智, 他 中津市民病院小児科 伊藤創太郎，他 宮崎大学医学部小览科 田中悦子, 他 
日览腎誌 Vol. 25 No.1

\section{一般 演題}

1 . 1 型糖尿病に微小変化型ネフローゼ症候群を合併した 1 症例

九州大学医学部小览科 西山 慶

福岡市立こども病院・感染症センター内分泌代謝科＼cjkstart河野敦子 福岡市立こども病院・感染症センター腎疾患科 島袋 渡, 郭 義胤

【はじめに】1型糖尿病と微小変化型ネフローゼ症候群の合併はまれである。糖尿病に合併する腎障害として糖尿病 性腎症に伴うネフローゼ症候群が知られているが, 微小変化型ネフローゼの合併はそれぞれ単独の発症率から推定す るとおよそ300万人に 1 人とされている。

【症例】10歳男児。

【既往歴】5歳時に糖尿病性ケトアシドーシスで 1 型糖尿病を発症し，在宅インスリン注射で加療されていた。血糖 コントロールは比較的良好であった（HbAc 8.4\%）。

【現病歴】 9 歳 7 か月時に腹痛, 嘔吐, 浮腫が出現。低 $\mathrm{Alb}$ 血症 (Alb 0.6mg/d $\ell$ ) と高度尿蛋白 (U-P/Cr 21.3) か らネフローゼ症候群と診断された。プレドニン（PSL）60mg 連日内服を開始したところ，一時は食前血糖300～500 $\mathrm{mg} / \mathrm{d} \ell$ と著明な高血糖を呈した。内分泌代謝科と協力し，強化インスリン療法による厳密な血糖管理を行った。治療 開始から 2 週間経過しても尿蛋白改善傾向はなく, シクロスポリンの併用を開始した。同時期に施行した腎生検では minor glomerular abnormalities であった。加療開始より 4 週間後に完全寛解が得られた。その後 PSLを隔日投与にし て漸減，約 6 か月後に中止したが，5 日後に再発した。再発後はPSLの再開により10日後に寛解した。PSL 開始後 の HbA 1 c は 1 か月後7.7\%，2 か月後7.8\%と良好な血糖コントロールが可能であった。

【結語】1型糖尿病に合併した微小変化型ネフローゼ症候群にPSL 投与を行った。高血糖に対しては強化インスリ ン療法による厳密な管理が有効であった。

2.リツキシマブ単回投与を行い，その後ミコフェノール酸モフェチルを用いて寬解を維持しているステロイド抵抗 性ネフローゼ症候群の 5 歳女児例

熊本大学医学部小児科 服部希世子，仲里仁史，河野智康，米田香織，阿南浩太郎，遠藤文夫 近年，難治性ネフローゼ症候群の小児にリッキシマブ（RTX）が投与され有効であるとの報告がなされ，新しい有 効な薬剂として期待されている。また，ミコフェノール酸モフェチル（MMF）も難治性ネフローゼ症候群に対して 有効であるとの報告がみられる。今回我々はステロイド抵抗性ネフローゼ症候群に対してステロイドパルス療法, シ クロスポリン $(\mathrm{CyA})$ ，ミゾリビン（MZR）併用を行ったが寛解に至らず，RTX 単回投与を行ってその後 MMF 投与 にて寛解を維持している症例を経験したので報告する。

症例は 5 歳女児。平成19年 3 月（1歳 4 か月時）にネフローゼ症候群を発症し, PSL 投与28日目に不完全宽解のた め, ステロイド抵抗性ネフローゼ症候群と判断し腎生検を行った。その結果, 巣状系球体硬化症の診断であった。そ の後 CyA を開始し寛解を維持していたため，平成21年10月にCyA 中止した。CyA 中止 3 か月後の平成21年12月に 再発を認めた。このときはPSL+MZRによる治療で再び寛解となったが, 平成 22 年 3 月に感冒症状に伴って再発 ( 2 回目）を認め当科入院となった。入院後，PSL 増量 + MZR 併用にて治療を行ったが，寛解に至らなかったため平成 22年 5 月にステロイドパルス療法を開始した。ステロイドパルス療法 3 クール目後には寛解となり，平成 22 年 7 月に 2 回目の腎生検を施行した。その結果，微小変化型に近い組織像であった。CyAによる慢性腎障害は認めなかった ので, CyAの併用を開始した。しかし, その後, ステロイドパルス療法8クール施行するが寛解に至らなかった。 平成23年 1 月ステロイドパルス療法 9 クール目を行い，その直後RTX 300mg 単回投与を行った。その後，ステロイ ドパルス療法10クール目を施行し寛解となり，平成23年 2 月より MMF 導入した。RTX 投与後 4 か月経過した現在 も MMF 投与にて寛解を維持している。 
日児腎誌 Vol.25 No. 1

3.サイトメガロウイルス感染後に慢性血小板減少症をきたした腎移植後の 1 例

鹿児島大学医学部小児科 永迫博信, 久保田知洋, 河野嘉文

済生会川内病院小児科＼cjkstart森田康子，田中主美

東邦大学医療センター大森病院腎センター 宍戸清一郎

【症例】症例は11歳の男子。学校検尿で蛋白尿の異常があり，7歳 6 か月時に当科外来を初診。低異形成腎による保 存期腎不全と診断し, 内服薬による保存的加療を行っていたが, 腎機能は徐々に増悪。9 歳 8 か月時に東邦大学医療 センター大森病院腎センターにて父親をドナーとして生体腎移植を施行 $(C M V R-/ D+)$ 。術後経過は良好で移植後 55日に退院。同センター退院後は当科でのフォローを再開。

移植後 1 年 3 か月時に微熱，下痢が持続するため，当科関連病院小児科を受診。血液検査で血小板減少 $(8000 / \mu l)$ を認め, 同院入院。入院後には，高熱があり，MMF は一時中止。入院時に CMV 抗体検査を提出しており，IgM が陽 性であったため, CMV のアンチゲネミア検査を提出。陽性を確認し CMV 感染症と診断した。ガンシクロビル (GCV) での加療を行い, CMV アンチゲネミアの陰性化を確認後に GCV は中止し，MMF を再開した。入院 2 か月後に血小 板が $3 \sim 4$ 万/ $\mu$ ま で回復し，退院。退院後は当科外来での通院加療を行い，血小板減少症が遷延したため，MMFは $1 / 2$ 量投与への減量は発症 7 か月時点でも継続している。

【考察】臓器移植では, 本症例のような $\mathrm{CMV} \mathrm{R}-/ \mathrm{D}+$ +症例は, 移植後免疫抑制下にドナー由来の CMV が賦活化さ れ, 感染症に至る可能性が高くなり，八イリスク例となる。感染の時期としては，移植後早期（移植後 $1 \sim 4$ か月） に感染を起こすことが多い。しかし, 本症例では 1 年以降の発症で, 症状は下痢, 血小板減少, 発熱と非特異的であ り，悪性疾患も含めた鑑別まで行った。CMV 感染の治療としては，比較的早期に CMV 感染症の診断でき，免疫抑制 薬の減量とともに抗ウイルス薬を使用することで比較的スムーズに治療を行い, 重篤な症状の波及を防ぐことができ た。しかし，血小板減少に関しては比較的長期に遷延しているという問題は残っている。

CMV にはワクチンが存在せず，そのため早期診断，早期治療が重要となる。移植後の感染症としては，CMVは常 に念頭に置いておく必要がある。

4. 学校検尿でみつかった膜性増殖性系球体腎炎正型の 1 女巟例

愛媛県立今治病院小児科 手塚優子，藤澤由樹 愛媛県立新居浜病院小児科 海老原知博, 楠目和代 神戸常磐大学保健科学部医療検査学科 畑中道代，北野悦子，北川 肇 症例は 6 歳女児。 5 月の学校検尿で蛋白尿を指摘され近医受診。急性腎炎症状やネフローゼはなく, 低補体血症を 認め, 次第に尿蛋白が増加し, 低補体血症の改善がないため, 7 月に当科を紹介された。当科初診時, 血圧正常, 浮 腫はなく, 皮疹や関節症状などみられなかった。検尿では, 早朝尿蛋白 $3+($ 任意尿 $3+$ ), 潜血 $2+$, RBC $1 \sim 4$ / $\mathrm{HPF}, \mathrm{Upro} / \mathrm{Cr}=1.8, \mathrm{U}-\beta 2 \mathrm{MG}: 120 \mu \mathrm{g} / \ell, \mathrm{U}-\mathrm{NAG}: 7.6 \mathrm{U} / \ell$, SI 0.08, $24 \mathrm{hr}$ 尿蛋白 $550 \mathrm{mg} / \mathrm{day}, \mathrm{Ccr}=135 / \mathrm{m} \ell / \mathrm{min} /$ $1.73 \mathrm{~m}^{2}$ 。血液検査では BUN 13.5mg/d $\ell, \operatorname{Cr} 0.3 \mathrm{mg} / \mathrm{d} l$, TP $5.9 \mathrm{~g} / \mathrm{d} l$, ALB $3.5 \mathrm{~g} / \mathrm{d} l$, T. Cho $224 \mathrm{mg} / \mathrm{d} l$, ANA 40倍, ASLO : $88 \mathrm{IU} / \mathrm{m} \ell, \mathrm{CH}_{50}: 11 \mathrm{U} / \mathrm{m} \ell, \mathrm{C}_{3}: 10 \mathrm{mg} / \mathrm{d} \ell, \mathrm{C}_{4}: 9.0 \mathrm{mg} / \mathrm{d} \ell$ 。腎生検では, 総糸球体30個のうち, 硬化糸球体 1 個, 25個の糸球体でメサンギウムの増殖があり, 軽度の分葉化や係蹄壁の肥厚を認めた。半月体形成はなかった。 PAM では基底膜の二重化が明らかで，蛍光抗体法では C 3 c が Mes 領域と係蹄壁に強陽性，IgM 陽性であった。電顕 では，基底膜内にDeposit を多く認め，基底膜は不規則に肥厚していた。DepositはMes 領域や上皮下にも一部認め られた。MPGN として, mPSL-pulse 3 クール，MZR，抗凝固療法，抗血小板療法，ACE-Iによるカクテル療法を開 始, その後 PSL $1 \mathrm{mg} / \mathrm{kg}$ 連日投与後, 隔日投与で漸減している。尿蛋白は比較的速やかに減少し, 治療開始後約 2 か 月で陰性化し，現在尿所見は正常化している。 $\mathrm{CH}_{50}$ と $\mathrm{C}_{3}$ は pulse 終了後から上昇し，現在は安定している。

MPGN 型分類では，基底膜内の Deposit が主体であることから，MPGN II 型も疑われたが，連続性のものではなく， 蛍光抗体の所見からも「血型 Strife and Anders 型」と考えられた。低補体血症についての精査では, Alternative pathway の活性化が考えられたが，H 因子は正常であった。また血漿の C 3 活性，蛋白濃度が保たれており，C $3 \mathrm{NeF}$ の 関与の可能性は低いと考えられる。MPGN II 型では二次性の検索も重要であり, 今後 SLE 症状の出現などに留意し つつ経過をみている。 
5 . 血尿・低補体血症で発症し， 3 年後に腎生検を施行した MPGN の 1 例

国立病院機構西別府病院小児科 植村篤実，平松美佐子 熊本保健科学大学＼cjkstart服部新三郎

【症例】14歳男児。

【主訴】蛋白尿, 血尿。

【現病歴】2007年（小学 5 年生）の学校検尿で尿潜血 $1+(\mathrm{RBC} 7 \sim 10 / \mathrm{HPF}), \mathrm{CH} 50$ 20U/mlだったが，血尿症候 群, 要管理 $\mathrm{E}$ とされ受診指示なし。2008年は尿潜血 $+/-(\mathrm{RBC} 50 / \mathrm{HPF})$, 血尿症候群, 要管理 $\mathrm{E} 。 2009$ 年（中学 1 年生）の学校検尿で蛋白 $1+$, 潜血 $2+$ であり，11月30日当院初診。腎生検のため 2010 年 7 月 22 日入院。

【入院時現症】身長 $168 \mathrm{~cm}$, 体重 $51.9 \mathrm{~kg}, \mathrm{BP} 110 / 62 \mathrm{mmHg}, \mathrm{PR} 69 /$ 分。浮腫・紫斑・皮疹なし。

【検査所見】血液；TP 6.5g/d $\ell$, ALB 4.3g/d $\ell$, ALP $471 \mathrm{IU} / \ell$ ，T-CHO 136mg/d $\ell$, BUN 7.2mg/d $\ell$, CRE 0.61mg/d $l$,

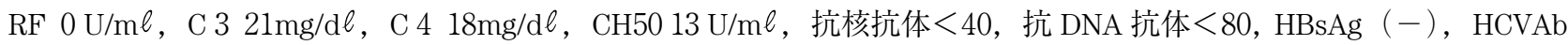
(-). WBC 4280，RBC 472万，Hb 13.3g/de，Plt 24.9万， ESR $5 \mathrm{~mm} / 1 \mathrm{hr} 。$

尿; 蛋白 $1+(59 \mathrm{mg} / \mathrm{d} \ell, 1$ 日尿蛋白 $0.20 \mathrm{~g})$, 潜血 $3+(\mathrm{RBC} 20 \sim 29 / \mathrm{HPF})$, Ccr $127.1 \mathrm{~m} \ell / \mathrm{min} / 1.73 \mathrm{~m}^{2}$. U-cre $52.9 \mathrm{mg} / \mathrm{d} \ell$, U-NAG $15.6 \mathrm{IU} / \ell, \mathrm{U}-\beta 2 \mathrm{MG} 44 \mu \mathrm{g} / \ell$ 。

【経過】2010年 7 月27日，腎生検施行。36個の系球体すべてに 中等度一高度のメサンギウム細胞増生と基質の蓄積 を認めた。GBM二重化とメサンギウム・上皮下・内皮下に沈着を認めた。C 3 がメサンギウムと係蹄壁に強陽性を 示し，MPGN と診断した。硬化系球体，間質線維化，半月体は認められなかった。8月24日にステロイド開始。 mPSL パルス $(500 \mathrm{mg} \times 3 ） 3$ クール，後療法はPSL 30mg 連日内服， dipyridamole を併用した。2 3 週経過後に尿蛋白 減少・補体上昇傾向が認められた。治療開始 8 週後にPSL 50mg 隔日とした。12月以降尿所見正常, C 3 70 80mg/ $\mathrm{d} l, \mathrm{CH} 50$ 29 31 U/ml。2011年 3 月 1 日, 第 2 回腎生検, メサンギウム増殖・ GBM 二重化・沈着は軽減していた。 5 月10日から MZB, ACEI 追加, PSL 40mg 隔日に減量した。

【考察】発症から 3 年経過した MPGNで, 組織では慢性障害所見は認められていないが早い時期での治療とはいえ ない。今後の治療や 3 回目の腎生検の時期について検討が必要である。

6. 抗 Factor H 抗体にて発症した atypical HUS（aHUS）の 1 例

佐賀大学医学部小児科 岡 政史, 大塚泰史, 稲田由紀子, 石松菜那, 佐藤忠司, 濱崎雄平

4 歳 5 か月，男児。11月24日から 3 日間，頬部と口唇の腫脹，頭部と背部の掻痒感に対しステロイド剤の外用およ び内服を受けていた。12月 1 日朝より機嫌不良と頻回の嘔吐が出現し，その後紫斑を伴った。12月 2 日近医を受診 し，点状出血，顔色不良と血液検査にて貧血，血小板減少を指摘され当院へ搬送された。

当院では高血圧（BP 127/83mmHg）を認め，意識清明だが活気にそしかった。皮膚は蒼白，全身に $1 \sim 2 \mathrm{~mm}$ の点状出血が散在していた。血液検査で, 貧血 $(\mathrm{Hb} 4.2 \mathrm{~g} / \mathrm{d} l)$, 破砕赤血球，血小板減少（PLT $1.5 \times 10^{4} / \mu l ）$ あり。 腎障害（BUN 88.0mg/d $\ell$, Cr 1.51mg/d $\ell$, CysC 1.73mg/ $\ell$ ） と低補体血症 $\left(\mathrm{C}_{3} 50 \mathrm{mg} / \mathrm{d} \ell, \mathrm{C}_{4} 27 \mathrm{mg} / \mathrm{d} \ell, \mathrm{CH}_{50} 52 \mu / \mathrm{d} \ell\right.$ ) を認めた。また抗核抗体は上昇なく (ANA 40倍), ADAMTS 13活性 (104.2\%) とインヒビター $(<0.5 \mathrm{BUN} / \mathrm{m} \ell)$ は それぞれ正常だった。便培養で腸管出血性大腸菌の検出なく，簡易べロ毒素定性検査も陰性だった。

以上より aHUS と診断した。FFP 投与を行うも反応は一時的だったため，血漿交換療法を開始した。PEX 5 回施行 し，血小板数，貧血，腎障害の改善を認め29病日に退院した。

低補体のため FactorH の検索を優先し，Factor H 低下 $(268.27 \mu \mathrm{g} / \mathrm{m} \ell$ : 対照の $53 \%)$, ELISA 法にて抗 FactorH の 存在を確認した。遺伝子検査についてはSNP array を行いCFHR 1 と CFHR 3 遺伝子を含む欠失（139kb）を認めた がへテロ接合体変異であった。今後 Factor H 遺伝子検査を行う予定である。 
日览腎誌 Vol.25 No.1

7. Hyponatremic hypertensive syndrome（HHS）を呈した 1 女児例

長崎大学医学部小児科 原田定智, 白川利彦, 中嶋有美子，森内浩幸

【症例】 8 か月の女児。

【主訴】発熱, 嘔吐。

【家族歴】長女は健常，次女は Costello 症候群・肥大型心筋症で死亡。

【経過】X 年 3 月19日，および23日以降高熱が持続し25日には嘔吐を認め近医受診。脱水，血尿，蛋白尿を認め， 当科へ紹介。

【入院時所見】活気がない状態。体温: $38.2^{\circ} \mathrm{C}$, 脈拍: 126 回/分, 血圧: 94/73mmHg, 呼吸数: 26/分, $\mathrm{SpO} 2$ : $97 \%$ ，眼窩軽度陥没，浮腫なし (血液検査) WBC 3900/ $\mu$, Hb 12.4g/d $\ell$, PLT 14.6万 $/ \mu \ell$, TP 5.4g/d $\ell$, Alb 2.4g/d $\ell$, BUN $8 \mathrm{mg} / \mathrm{d} \ell$, Cre $0.32 \mathrm{mg} / \mathrm{d} \ell$, Na $126 \mathrm{mEq} / \mathrm{L}, \quad$ K $3.4 \mathrm{mEq} / \mathrm{L}, \quad \mathrm{Cl} 88 \mathrm{mEq} / \mathrm{L}, \quad$ CRP $0.11 \mathrm{mg} / \mathrm{d} \ell, \quad \mathrm{PRA} \geqq 20 \mathrm{ng} / \mathrm{m} \ell / \mathrm{hr}, \quad>$ ルドステロン $1570 \mathrm{pg} / \mathrm{m} \ell$, 静脈血液ガス分析 $\mathrm{pH} 7.551, \mathrm{pCO} 232.9 \mathrm{mmHg}, \mathrm{HCO}_{3}^{-} 28.8 \mathrm{mmol} / \mathrm{L}, \mathrm{BE} 6.6 \mathrm{mmol} / \mathrm{L}$ (尿検 査) 蛋白 $3+$, 潜血 $+/$, 糖 + , 蛋白定量 $1172 \mathrm{mg} / \mathrm{d} \ell$, Cre $24.1 \mathrm{mg} / \mathrm{d} \ell, N A G 60.3 \mathrm{IU} / \mathrm{L} ， \beta 2$ ミクログロブリン 27495 $\mu \mathrm{g} / \mathrm{L}$ （腎エコー）右腎 $5.3 \times 2.7 \mathrm{~cm}$, 左腎 $7.2 \times 3.5 \mathrm{~cm}$ （腹部造影 $\mathrm{CT}$ )，右腎萎縮，左腎腫大，右腎動脈・腹部大動脈 の狭小化とその周囲に腫瘤の集簇あり。

【入院後の経過】脱水の補正後，発熱・嘔吐は消失したが，高血圧が出現し，降圧治療を開始した。

【考察】症状，検査データより高安動脈炎によるHHS と考えられたが，入院当初は高血圧・多尿を認めなかった点 が病態把握を困難にした。片側腎動脈狭窄を呈する症例ではHHS の病態を考慮した対応が必要である。

8．発熱を契機に腎性尿崩症と診断した 1 例

中津市民病院小児科 伊藤創太郎，寺町昌史 福岡大学医学部小児科 山㟝靖人, 瀬川芳恵, 川谷恵里, 廣瀬伸一

高木病院小児科 福間裕子 福岡山王病院小児科 新居見和彦

【症例】日齢 8 男児 主訴: 発熱 家族歴：母が多飲傾向（精査なし）。

現病歴：妊娠中特記事項なく, 在胎 40 週 5 日, $3608 \mathrm{~g}$ で仮死なく出生。日齢 1 に近医産科にて $39.3^{\circ} \mathrm{C}$ の発熱・ CRP $0.8 \mathrm{mg} / \mathrm{d} \ell$ 。当科新生児室に入院。抗菌薬投与し解熱。日齢 7 に退院。日齢 8 と日齢 10 に $38^{\circ} \mathrm{C}$ 台の発熱があり精査目 的で当科入院。

入院時現症：哺乳は80 100m $/$ 回程度できており, 全身状態は良好であったが, 口腔内はやや乾燥, 他臨床所見 なし。

入院時検査所見：WBC 19000/ul，BUN 18.1mg/d $\ell$, Cr 0.5mg/d $\ell, N a 150 \mathrm{mEq} / \ell$, CRP 0.9mg/d $\ell$ 。

入院後経過：入院時より高張性脱水と高 $\mathrm{Na}$ 血症，尿比重低值があり，入院後に多尿 $(7 \mathrm{~m} \ell / \mathrm{kg} / \mathrm{hr} \sim 10 \mathrm{~m} \ell / \mathrm{kg} / \mathrm{hr})$ が明らかとなった。血清浸透圧 $310 \mathrm{mOsm} / \mathrm{kg}$, 尿浸透圧 $101 \mathrm{mOsm} / \mathrm{kg}$, AVP $22.5 \mathrm{pg} / \mathrm{m} \ell$, 頭部 MRI で異常所見はなかっ た。AVP 負荷試験を行い尿浸透圧・尿中 cAMPの上昇がないために完全型腎性尿崩症と診断した。治療は希釈ミル クの摂取・輸液にて血清 $\mathrm{Na}$ は改善し $140 \mathrm{mEq} /$ 程度に安定した。経過中に尿量が増加したためサイアザイド内服を 開始し尿量は減少した。後日 V 2 R 遺伝子異常が判明し，先天性腎性尿崩症と診断した。

【考察】発熱を機に新生児期に診断されたV $2 \mathrm{R}$ 遺伝子異常による先天性腎性尿崩症を経験した。輸液・希釈ミル ク・サイアザイド内服にて軽快した。現在 $\mathrm{Na}$ 制限はせずに発達や成長は問題ないが，今後も注意深い観察が必要と 思われる。

9. 精神運動発達遅滞を伴う児に腹膜透析を導入した 2 例

宮崎大学医学部小児科 田中悦子，織田真悠子，此元隆雄，中原彰彦，池田俊郎，布井博幸

医療技術や福祉制度が向上し，重症心身障害児の生命予後は改善した。それに伴い，腎代替療法の適応となる重症 心身障害児が増加していると思われる。今回，重度精神運動発達遅滞を伴う児の維持腹膜透析導入を 2 例経験した。 障害を伴う児の腎代替治療は, 患者の体格や遅滞の程度, 主訴のそしさ, 基礎疾患による合併症や予後, 家族のサポー ト状況など特有の問題があり，小児腎専門医以外の医師や職種との連携，計画的な導入とその後の注意深い管理が必 
要である。

症例 1 は， 7 歳男児。生後から Dandy-walker 症候群による水頭症があり VP シャント術後，大島分類 1 の重症心 身障害児である。2011年 4 月, 発熱時に施行した血液検査で, BUN 137.3mg/d $l$, Cre 10.2mg/d, Ccr $5 / \mathrm{m} l / \mathrm{min} /$ $1.73 \mathrm{~m}^{2}$ と著明な腎機能障害を認めた。当科入院後, 腎不全の原因は不明であったが緊急に腹膜透析を開始した。そ の後も腎機能の回復はなく維持腹膜透析へ移行，家族のサポートがあって在宅腹膜透析を行っている。 症例 2 は，10歳男児。2011年 2 月にコケイン症候群と診断された大島分類 5 の重症心身障害児である。2010年 7 月 に蛋白尿と腎機能障害, 代謝性アシドーシスがあり, 内服加療を開始。2011年 5 月に活気低下があり, 血液検査で, BUN $54.8 \mathrm{mg} / \mathrm{d} l$, Cre $3.23 \mathrm{mg} / \mathrm{d} \ell, C c r 5 \mathrm{~m} l / \mathrm{min} / 1.73 \mathrm{~m}^{2}$ と著明な腎機能障害増悪を認め, 心拡大と肺水腫, 高血圧を 伴う溢水状態であった。コケイン症候群による腎不全と診断した。各種薬剤に抵抗性の高血圧と肺水腫が持続したた め間欠的 HDF を施行後に PD カテーテル挿入術施行, 腹膜透析へ移行した。しかし, 横隔膜交通症のために腹膜透 析を中断しており，基礎疾患の生命予後のために，今後の腎代替療法の適応が問題である。 